\title{
DEVELOPING INTERCULTURAL COMPETENCES AND CREATIVITY: THE FOUNDATION FOR SUCCESSFUL INTERCULTURAL COMMUNICATION
}

\author{
Justinas BRASLAUSKAS (1)* \\ Department of Creative Communication, Faculty of Creative Industries, \\ Vilnius Gediminas Technical University, Traku str. 1, 01132, Vilnius, Lithuania
}

Received 18 October 2020; accepted 28 April 2021

\begin{abstract}
Although various aspects of intercultural communication have been examined in the works of various authors, there is still a lack of more in-depth research to analyse effective intercultural interaction in the context of combining intercultural competences and creativity competences. A number of works on intercultural communication identify only the barriers to effective communication and provide ways to overcome them; they insufficiently focus on the importance of competence development, in particular the role of creativity in ensuring effective intercultural communication. Meanwhile, the role of creativity as a process of generating new ideas and solving problems in intercultural communication is undeniable. There is no doubt that in order to ensure effective intercultural communication, it is necessary to combine intercultural competences with creativity competences. The object of this study is the development of intercultural competencies and creativity competencies in the context of intercultural interaction. The aim of this article is to examine the development of intercultural competencies and creativity as a basis for successful intercultural communication. Through the works of various scholars, the article describes the aspects of intercultural competences and creativity competence development in the context of intercultural interaction, and emphasises the importance of combining these competencies in order to achieve effective intercultural communication. The following methods are applied in the work: analysis and synthesis of scientific literature.
\end{abstract}

Keywords: creativity, development, development strategy, intercultural communication, intercultural competences.

\section{Introduction}

Although various aspects of cross-cultural communication have been addressed in the work of various authors (Jiaquan, 2009; Lustig \& Koester, 2012; Jackson, 2014; Martin \& Nakayama, 2018; Jandt, 2020; Neuliep, 2012), there is still a lack of more in-depth research to analyse effective intercultural interaction in the context of combining intercultural competences and creativity competences. A number of works on intercultural communication identify only the

\footnotetext{
${ }^{\star}$ Corresponding author. E-mail: justinas.braslauskas@vilniustech.lt
} 
barriers to effective communication and provide ways to overcome them; they insufficiently focus on the importance of competence development, in particular the role of creativity in ensuring effective intercultural communication. Meanwhile, the role of creativity as a process of generating new ideas and solving problems in intercultural communication is undeniable. There is no doubt that in order to ensure effective intercultural communication, it is necessary to combine intercultural competences with creativity competences.

Problem of research. Insufficient awareness of the importance of developing intercultural competencies and creativity in order to achieve effective intercultural communication.

The object of the study is the development of intercultural competences and creativity competences in the context of intercultural interaction.

The aim of this article is to examine the development of intercultural competences and creativity as a basis for successful intercultural communication.

To achieve this goal, the following tasks are pursued: 1) to analyse the concept and structure of intercultural competence; 2) to examine the importance of intercultural competence in intercultural interaction; 3 ) to analyse creativity as a process of generating new ideas and solving problems in intercultural interaction, to conceptualise the importance of this phenomenon; 4) to examine in detail the constituent competences of intercultural competence, using a structured form of discussion - structuring them by levels, dimensions, etc. 5) to analyse the strategy of intercultural competence development; 6) to analyse the aspects of developing creativity at the educational institution and at the workplace.

The following methods are applied in the work: analysis and synthesis of scientific literature.

\section{Importance of intercultural competences and creativity in intercultural interaction}

\subsection{The concept and structure of intercultural competence}

The concept of intercultural competence relates to the readiness to accept differences and includes both social and cultural aspects.

Scholars are not united on the definition of intercultural competence. Various definitions of intercultural competence predominate in the academic literature.

Based on the idea that competencies encompass everything that a person actually can and knows that competence is like a system of internal mental conditions that is reflected in the quality of visible actions, Geistmann (2002, pp. 34-37) presents the main components of intercultural competence that can be considered as a basis for the development of intercultural competence: cognitive components of conscious behaviour - knowledge; affective components of conscious behaviour - emotions. Intercultural competence is described as the search for a balance between one's own and others' interests and needs that stem from different cultural contexts.

According to Pruskus (2013, p. 85), Samovar et al. (2011) describe the meaning of intercultural competence as follows:

- a set of components comprised of various manifestations of knowledge, abilities, traits, attitudes, affecting cognitive and behavioural processes in an intercultural context; 
- the individual's ability to work effectively in a diverse environment;

- the individual's ability acquired on the basis of knowledge, skills and attitudes, to work effectively in the context of interaction of different cultures which is achieved through successful mediation and capacity building.

Herbrand (2000, pp. 43-46) defines intercultural competence as the ability to understand another (and one's) culture and the ability to act appropriately, adequately, including all the skills required for this, and divides intercultural competence into three interdependent dimensions: cognitive (intercultural knowledge, i.e. theoretical knowledge of other cultures, commonalities and differences between cultures); affective (intercultural sensitivity, i.e. personal traits such as openness and tolerance, empathy and a person's favourable attitude towards intercultural contacts); communicative - behaviour-oriented (abilities and skills to communicate successfully and behave appropriately).

Jiaquan (2009, p. 28) defines intercultural competence as the ability to interact with people from other cultural backgrounds, which includes three aspects: formation of cultural awareness (including a comprehensive understanding of one's own culture and attitudes towards other cultures); awareness of cultural knowledge; developing intercultural interaction skills and the ability to use them effectively in intercultural situations.

Petkevičiūtè and Budaitè (2005, p. 136) describe intercultural competence as the ability of an individual (or organisation) to work effectively in a diverse environment. The authors also note that the following elements of intercultural competence content are commonly identified: cultural awareness; cultural knowledge; cultural sensitivity or cultural attitudes; cultural skills.

As we can see, it is difficult to single out a common definition of intercultural competence, all the more so as other authors (Wiseman \& Koester, 1993; Jandt, 2000; Byram, 1997; Stone, 2006; Mažeikienė \& Virgailaitė-Mečkauskaitė, 2007; Mažeikienė \& Loher, 2008; Deardorff, 2009; Virgailaitė-Mečkauskaitè, 2011; Martin \& Nakayama, 2018; Neuliep, 2012) define it differently and offer different models. Summarising the models presented in the scientific literature, it is possible to agree with the statement of Norviliene (2014b, p. 42) that the following levels are distinguished in the models of all authors: 1) level of cognition (knowledge of one's own and other cultures, cultural differences, similarities, cultural norms, beliefs, values, etc.); 2) emotional level (personal traits, attitudes, emotions, feelings, etc.); 3) behavioural level (highlighting the application of knowledge, abilities, attitudes, cultural experiences in intercultural interaction and cooperation).

The level of each model is comprised of certain structural components. Norviliene (2014b, p. 42) singles out the fifteen most common structural components necessary for people living in a multicultural society and seeking intercultural dialogue: 1) respect for another culture; 2) openness; 3) tolerance for ambiguity; 4) flexibility; 5) empathy; 6) curiosity and desire to discover, to learn; 7) cultural knowledge; 8) cultural understanding; 9) ability to listen and hear the interlocutor's point of view; 10) ability to monitor; 11) ability to interpret and compare; 12) ability to analyse and evaluate; 13) ability to resolve/avoid conflicts; 14) foreign language skills; 15) understanding of nonverbal language. 


\subsection{The importance of intercultural competence in intercultural interaction}

Acquired intercultural competence skills help us to communicate effectively with representatives of other cultures both during private trips, travels, and in the context of business intercultural interaction.

The importance of intercultural competence is particularly evident in intercultural official interaction, as this interaction usually takes place continuously between representatives of different cultures in business, politics, science, culture or similar fields, rather than occasionally as on various tourist or similar trips. Intercultural competence skills are also very important for persons working abroad.

Intercultural competence is also important in one's home country. Intercultural competence is important for companies that seek to establish contacts with foreign organisations or want to maintain and strengthen them. Intercultural competence is also important for organisations with multicultural staff, representing more than one culture. In a global world, the number of multicultural teams will only grow. Insufficient intercultural competence causes problems related to: 1) different time planning and management; 2) different temperaments of communicators; 3) different work culture, rules of conduct; 4) different perceptions of managerial and subordinate relationships.

\subsection{Creativity as a process of generating new ideas and solving problems in intercultural interaction}

The "approach" itself to the representatives of cultures of different mentalities should be original, creative, therefore, it is clear that effective intercultural communication must contain elements of creativity. This trait must be developed. Rakauskaite (2014, p. 337) identifies five prerequisites for disclosure of a creative approach: 1) the main condition is the ability to be surprised; 2) the ability to concentrate, to perceive oneself as real sent to the world, able to create, and at the same time transcend one's personal boundaries, merging with others, feeling unity with the world; 3) personal, "I" experience; 4) the ability to accept conflict and stress rather than avoid them. The tension arising from polarity is a condition of human existence necessary for the development of spiritual strength and creative imagination; 5) courage and faith that allows to trust one's experience and any new experience to emerge.

Creativity is often associated with the ability to generate new ideas and solve problems. Savanevičienè and Gudonavičius maintain that creativity

"can be defined as a creative effort that manifests itself in human activity and thinking, while at the same time expressing novelty and originality, and on the other hand, enabling a targeted and exclusive solution to technical, human or socio-political problems" (2007, p. 638).

In intercultural interaction, various problems arise constantly. The problem arises when a person does not know how to move from the current undesirable situation to the desired situation. If the solution of the problem corresponds to the criteria of the creative work, in intercultural interaction, as in other life situations, the solution of the problem (as a process) can be considered as creative thinking. 
The importance of creative thinking is not only significant in informal communication between representatives of different nationalities, but also in intercultural business communication. For example, creative thinking is very important in cross-cultural teams, international negotiations or other similar international meetings, solving problems and generating new ideas. A model of the process of realising creativity can be described by the following sequence: 1) fixation phase of problem tracking and identification or needs. Observing a need or problems may occur unconsciously, but once identified and recorded, it can trigger the processes of analytical thinking and creativity; 2) preparation. The preparation phase involves seeking and analysing factual information about the current situation; 3 ) incubation (suspension). In the incubation phase, the idea is matured until it emerges in a holistic, systematic way; 4) systematic description of ideas. In this phase is invoked creativity when the other phases can be used for analytical thinking; 5) solution-finding. In this phase are generated possible courses of actions on implementing the idea; 6) evaluation. In the evaluation phase, the results of the idea are evaluated (Peleckis et al., 2013a, p. 40; Peleckis, 2014, p. 66). In order to make good use of creative thinking in an intercultural context, the level of creativity of the participants in the intercultural communication must be taken into account when organising meetings.

Various models of the creative thinking process have been studied by a number of authors (Wallas, 2014; Cropley, 1999; Ruggiero, 2011; Griffiths \& Costi, 2019). The models of the creative thinking process of the aforementioned authors are suitable for solving any problem that has arisen in a life situation, therefore, it is obvious that they are also applicable to situations of intercultural interaction. However, we will not discuss these models in this article because their discussion does not fall within the scope of the objectives of this article.

As mentioned above, creativity as a process of generating new ideas and solving problems is especially important in intercultural business communication. In the 21st Century Skills, Education and Competitiveness report, the role of creativity in organisations, including business organisations, was highlighted as the most important and articulated creativity-related abilities - solving complex, interdisciplinary, open-ended problems; creative and entrepreneurial thinking; innovative use of knowledge, information and opportunities (Partnership for 21 st Century Skills, 2008, p. 10). In order to survive, to be able to communicate effectively with each other internationally, organisations must offer solutions to the changing societal needs. The increasing pace of change increases the expectations for the creative skills of those working in the workforce and employee careers are increasingly open no longer confined to the improvement of one product or service.

Thus, only by perceiving the significance of creativity, it is possible to effectively communicate with foreign partners not only in the context of informal but also official interaction, conduct negotiations, and make innovative decisions. Rakauskaite (2014, p. 344) notes that creativity "is not a unique attribute of gifted people, but is achievable for every individual, it is a skill we need to develop". 


\section{Development of intercultural competencies}

\subsection{Intercultural competencies to be developed}

Direct intercultural contact is important in the development of intercultural competence, because then one's own cultural identity emerges, but intercultural competence is not acquired only through direct contact with another culture. Researchers unanimously state that this competence is acquired through purposeful discussions and teaching. It is a comprehensive, reflexive, conscious, complex, constant process of knowledge acquisition and personality development (Hinz-Rommel, 1994, pp. 32-35).

Human life and activities begin with inner things. As Tracy notes,

"the axis of personality is values. Values determine who a person is. Everything a person does in the external world is ordered and determined by inner values, whether they are clear or not. The clearer a person's inner values are, the more precise and effective the actions in the outer world are" (2010, p. 48).

It is important to realise that intercultural competence is developed in parallel with the general competences that a person develops throughout life: at secondary school, at higher school and afterwards (Peleckis et al., 2013b, p. 352). Intercultural competence also requires lifelong learning, open encounter with oneself and others, and is developed through intercultural learning.

Intercultural interaction competence requires certain knowledge, cognitive and practical skills, attitudes and values, motivation and the ability to apply knowledge in practice. Three essential levels of intercultural interaction competence can be distinguished:

- cognitive level, which includes an individual's ability to change their point of view;

- the emotional level, which includes the individual's feelings - fear, love, anger, panic, hatred, etc.;

- behavioural level related to an individual's ability to adapt or change his behaviour based on acquired cognitive or emotional level skills (Jančaityte et al., 2009, p. 91).

Maletzke (1996, pp. 128-129) notes the importance of skills for successful intercultural activities. In accordance with him, the basic skills required for such activities are subject competence, language knowledge and, in particular, the ability to establish positive social relationships, which can be developed and attributed to skills. Maletzke (1996, pp. 128-129) notes that in terms of intercultural interaction, the emphasis is usually placed on personal traits, abilities and skills, but unfortunately the conditions defining the situation in which those contacts take place are omitted. In his view, it is also necessary to attach importance to the situation and to try to take account of its influence on the behaviour of the contacting persons.

In intercultural competence, three levels can be distinguished that need to be fostered: linguistic, communication and cultural competences. Only the unity of these three competencies can ensure a successful intercultural dialogue (Pruskus, 2011, pp. 148-150, 2013, p. 85). There is a considerable amount of works examining these levels of intercultural competence. For example, Jackson (2014), McConachy (2018), Carrió-Pastor and Bellés-Fortuño (2021) examined linguistic competence in the context of intercultural competence, Domingo (2018), Fantini (2019) examined communication competence, Rothman (2007), Berardo and Deardorff 
(2012), Zaldivar (2020) etc. examined cultural competence. In this article, we will confine ourselves to the basic insights that describe these three levels of intercultural competence.

Linguistic competence. In intercultural communication, linguistic competence means the ability to choose appropriate language tools for communication and to be able to repeat lessons learned in similar situations (Pruskus, 2011, p. 148, 2013, p. 85).

It is very important to know foreign languages in addition to one's mother tongue. Vaičiūnienè (2015, p. 27) notes that "interaction in any language means that the person must have a good amount of vocabulary, grammar and different functions of language". In addition, in accordance with the author,

"people need to be able to communicate in different situations, they should appreciate the aesthetic qualities of languages, interact with other people from different cultures in a multilingual environment. Languages are particularly relevant to creativity and emotion management, and to social and personal well-being" (Vaičiūniené, 2015, p. 27).

Garrido and Álvarez (2006, p. 165) note that intercultural competence as an important dimension of language teaching has been examined by many authors who attribute to languages the function of social justice or the spiritual education of the learner as a person. One of the most important language teaching documents is the Common European Framework of Reference for Languages: Learning, Teaching, Assessment (Council of Europe, 2002) which is based on the Byram's (1997) "savoir" model emphasising intercultural competence.

Communicative competence defines the ways and strategies necessary to ensure effective interaction. In other words, it is necessary not only to have a good understanding of a person's general patterns of life, but also to be sensitive to the slightest changes in a partner's behaviour during interaction (Pruskus, 2011, p. 149, 2013, p. 86).

According to Grebliauskienè and Večkienè (2004, p. 34), the development of communicative competence is characterised by continuous self-development, improving one's natural powers. It is communicative competence that allows answering questions such as: What information do I want to transfer?; Why does it seem important to me?; Why might it be important to the recipient of the information?; Do I convey this information comprehensively? Or, in other words, what are my responsibilities in interpersonal communication, what values, knowledge, skills and abilities determine my behaviour in the communication process?

Pruskus (2013, p. 86) provides the following elements of communication competence: 1) ability to interpret the specific signals of the representatives of a particular culture by which they express a willingness to interact (or not to interact); 2) the ability to orientate how much time should be spent listening to the partner and to speaking, depending on the situation and cultural norms of interaction; 3) ability to adequately express thoughts and understand the interlocutor; 4) ability to direct the language in the right path; 5) ability to provide and interpret communication roles and interaction completion signals; 6) to preserve a pleasant communication distance acceptable to that culture; 7) ability to use verbal and non-verbal means of cultural acceptance; 8 ) ability to adapt to the social status of communicators and intercultural differences; 9) the ability to adjust one's behaviour in a timely manner when interacting with partners. 
Abilities that guarantee communication competence are systematically related and cannot be exhaustive. They are nurtured throughout life by people by constant renewal (Grebliauskienè \& Večkienè, 2004, p. 29).

Cultural competence. It means the ability to absorb new knowledge, value attitudes inherent to the cultural environment of interaction. This requires the ability to extract the necessary cultural information from various cultural sources (books, films, political phenomena, etc.) and to differentiate the sources in accordance with their significance for communication. This shows the cultural literacy of the interlocutor. If the cultural literacy of both partners is more or less the same, it only encourages effective interaction. However, the level of cultural literacy of the partners does not always coincide. In the event of a significant discrepancy, the effectiveness of communication deteriorates and the partners feel certain discomfort. Then the attempts are made to compensate the lack of cultural competence by good speech and communication abilities. However, this is not always successful (Pruskus, 2011, p. 149, 2013, p. 86).

Byram (1997, pp. 31-55) in discussing intercultural competence, distinguishes five dimensions of this competence:

- attitudes and personal traits. It is curiosity and openness, readiness to interact with people from different cultural backgrounds, etc.;

- knowledge. These include various knowledge of the social groups of one's own and another culture, knowledge of the historical and present relationship between one's own and another culture, knowledge of the national interpretation of geographical space, etc.;

- skills of interpreting and relating the differences of other cultures. It is the ability to interpret events and documents of another culture, to explain and relate it to events and documents of one's own culture, etc.;

- skills of discovery and interaction with peoples of other cultures. It is the ability to acquire new knowledge about culture and cultural practices, the ability to readily apply that knowledge, attitudes and skills; the ability to identify the similarities and differences between verbal and non-verbal processes and to use them appropriately, etc.;

- cultural awareness (critical cultural awareness/political education). It is the ability to critically evaluate perspectives, practices, and performance products in one's own and other cultures and countries based on many criteria.

Below, we will review the specific intercultural competencies to be developed using Byram's (1997) model of intercultural competence, i.e. by classifying the various abilities, skills, and knowledge to be developed into the five model dimensions of intercultural competence identified by the author.

Intercultural competence dimension - attitudes and personal traits include the following competences to be developed: 1) openness/curiosity/cultural sensitivity (to other cultures, new experiences, new knowledge, new perspectives, others' values, willingness to take risks and experience something new, to communicate with people from different cultural backgrounds); 2) self-esteem/emotion management (this competency group includes elements such as: conscious self-assessment; positive "I" image; self-awareness; self-control; self-reflexion; self-confidence and responsibility; ability to take into account one's cultural identity; ability to manage stress, anxiety, other negative emotions; ability to observe, analyse, partici- 
pate in managing one's emotions, empathy); 3) tolerance (to frustration, stress, social exclusion, ambiguity, uncertainty, new things, differences) (Virgailaitè-Mečkauskaitè, 2011, p. 47).

These competencies presuppose an individual's behaviour based on the following values: tolerance for different opinions and behaviours of another culture; elimination of stereotypes, attitudes towards other cultures; being sincere, friendly, benevolent in dealing with representatives of other cultures; the ability to empathize with the situation of representatives of other countries (or students in the educational process) while working with them; sense of responsibility for one's own activities (in the educational process - academic) when working with representatives of other countries (or students) (Mauricienė, 2013, p. 34).

Intercultural competence dimension - knowledge includes the following competencies that need to be developed: 1) knowledge of cultural differences/cultural differences in specific regions; 2) cultural; geographical, historical, political, social knowledge; 3) knowledge of general culturally influenced thinking, interpretation, activities; 4) knowledge/understanding of the principles of intercultural communication; 5) knowledge of emblems, rituals, taboos, etc.; 6) knowledge of common historical connections; 7) knowledge of organisational and professional culture; 8) knowledge of own and other culture's social groups, products they create; 9) knowledge of the causes of misunderstandings, their origin, etc. (Virgailaitè-Mečkauskaite, 2011, p. 47).

An individual who has mastered the competencies assigned to this intercultural competence dimension, in interacting with representatives of other cultures, should be able to know well the cultural differences of other countries (different time, word concepts, etc.), historical, political and demographic facts, as well as traditions, customs, habits, etiquette, norms of behaviour, favourite conversation topics. He should also be well aware of taboo topics in other countries which are better not to discuss, as this may offend the interlocutor. Intercultural interaction would be enlivened and provided mutual trust if a person had learned the other country's key interaction phrases (words of greeting, farewell, etc.). For their part, students should be familiar with the fundamentals of education systems and teaching methods of other countries (especially those studying or intending to study abroad) in order to facilitate academic and interpersonal interaction (Mauricienè, 2013, p. 33).

Dimension of interpreting and relating to differences of other cultures include the following competencies to be developed: 1) ability to analyse and adequately understand different cultural contexts and respond appropriately; 2) ability to interpret events and documents of another culture, to explain and relate it to events and documents of one's own culture; 3 ) ability to recognise manifestations of ethnocentrism and interpret its origins; 4) ability to recognize and explain approaches of misunderstandings, etc. (Virgailaitè-Mečkauskaitè, 2011, p. 47).

After acquiring these competencies, a person should understand the attitudes of people from other countries towards our country, its population/nation (as representatives of a certain culture). Students (especially those studying or intending to study abroad) should be familiar with the main documents governing education and higher education in the European Union and in the countries in which they are located, in order to avoid various misunderstandings in a foreign academic environment (Mauriciene, 2013, p. 34).

Dimension of discovery and interaction with people of other cultures cover the following competences to be developed: 1) communication abilities (foreign language skills; ability to 
build contacts; understanding of nonverbal language; ability to communicate in different situations); 2) ability to work effectively in multicultural teams and/or in a multicultural environment; 3) flexibility of behaviour; 4) ability to resolve/avoid conflicts; 5) ability to create social networks with new people in different environments, to build trust; 6) ability to communicate in situations dominated by different interaction styles, rules, rituals, symbols; 7) ability to find and use the support of public and private institutions to facilitate contacts with representatives of another country or culture (Virgailaitè-Mečkauskaite, 2011, p. 48).

Acquisition of the above-mentioned competencies ensures an individual a high probability to establish close cooperation relations with representatives of other countries, to successfully maintain and develop those relations. In turn, by developing these competencies, students learn to communicate with the audience of students from another country, i.e. to be communicative, to overcome the fear of the audience. They also learn to take advantage of the diversity of the audience, i.e. when students from other countries share their knowledge, experience with local students and teachers. Teachers who have mastered the above-mentioned competencies, must be able to, having taken into account the cultural differences of other countries, in dealing with the situation when working with students from other countries, to choose appropriate methods of presenting the subject content (Mauriciene, 2013, p. 34).

Intercultural competence dimension - cultural awareness includes the following competences to be developed: 1) knowledge of social values, of social norms, of social systems; 2) knowledge of the impact of different values and attitudes driven by cultural identity on the interaction of individuals or groups; 3) perception of the influence of culture and language on cognitive and learning processes; 4) knowledge of cultural adaptation or adaptation processes; 5) ability to critically assess prospects, performance products in their own cultures and in other cultures and countries on the basis of a number of criteria (VirgailaitèMečkauskaitè, 2011, p. 48).

Having acquired the competencies of cultural awareness dimension, an individual must be able to observe, get to know, understand oneself and the environment. He must also be able to responsibly analyse and understand the meanings and validity of his beliefs, values, and behaviours. Another important quality that an individual acquires by developing the competencies of cultural awareness dimension is the ability to think critically, i.e. to distance oneself from the available knowledge and perception, to be able to distinguish facts and opinions, to analyse and interpret reality problems and ambiguities, to critically question the assumptions of social phenomena. Cultural awareness also enables the individual to take active action, through experience, to bring about change that changes reality and liberates (Stancikas, 2015, p. 136)

In summary, it can be stated that the intercultural competences identified in this chapter and their consistent acquisition enable to reduce intercultural tensions and the risk of conflict, create prerequisites and promote effective intercultural communication.

\subsection{Strategy for the development of intercultural competence}

The following approaches can be distinguished in the pedagogical concept - coexistence of cultures, comparison of cultures, anti-racism, development of critical thinking, which can be considered as a pedagogical strategy for the development of intercultural competence. 
Coexistence of cultures. First of all, it is necessary for everyone to be able to recognise one's identity, as intercultural learning cannot be limited to the topics of foreign cultures without being knowledgeable in one's own. Representatives of each culture value other people through the prism of own cultural values, behaviours, customs, and traditions. If there is no readiness for self-understanding, a review of one's points of view, thought patterns and ways of doing things, intercultural interaction is not possible either. Intercultural learning is perceptual learning, and perception leads to reflection when one begins to consider one's own point of view. Cultural barriers can be overcome by critical reflection of the individual and the development of the ability to communicate with foreigners. Perception and reflection as a basis for acceptance of other cultures (Paurienè, 2011, p. 124). Alexandrache (2019, p. 60) emphasises the importance of national cultural studies in the development of intercultural competences. According to the author, knowing their national culture, students will be better prepared to understand other cultures and to interact with people from other cultures; studying elements of own culture helps improve intercultural dialogue. The author states: "The real intercultural dialogue is done by the conscious of ethnic identity that wants to express itself and to reflect it in the other culture" (Alexandrache, 2019, pp. 60-61).

Basis for comparison of cultures is knowledge of other cultures. It helps to obtain information about the identities of others and at the same time indicates the tools for understanding that identity. There is a diversity of cultures in the world, the disclosure of which would bring invaluable benefits and acquisition of broader horizons. Effective knowledge of the main features of other cultures would reduce unpleasant surprises (cultural shock), provide insight in advance and facilitate successful interaction with the representatives of those nations (Pruskus, 2004, p. 24). Comparison of cultures explains the forms and conditions of life in different countries. All cultures are acceptable and recognised in cross-cultural comparisons (Paurienè, 2011, p. 124).

Knowledge of others to overcome differences can be gained through two strategies:

- seeking information on other culture(s);

- asking and listening for answers.

Search for information about culture(s). Attitudes are often based on ignorance. Interest in other cultures, customs, beliefs, points of view can help understand the messages sent by the representatives of those cultures. Information on other cultures can be found in a variety of sources: in books, articles, online, tourist guides, talking to people.

Asking and listening. People tend to feel better when interacting with others similar to themselves than with different people. This is natural. Listening, speaking and asking questions help to better share information and reduce uncertainties when communicating with other cultures. When starting to communicate with a stranger from another culture, it is important to share information, ask questions and listen. This will not be enough to overcome obstacles to interaction, but will be a good start to establishing a relationship (Jančaitytė et al., 2009, p. 89).

The task of anti-racial education is to pay attention to discrimination and racism, to the achievement of justice. The focus is on hostile, racist, ethnocentric activities of the majority culture against minority cultures. Racism combines people's traits with features and views them negatively. It is rooted in prejudices, stereotypes and hostile speculations about certain 
social groups. The individual with his personal qualities remains disregarded. Superstitions draw a dividing line that prevents a closer familiarisation with a particular culture. In intercultural learning, people cannot be categorised, as this ruins the communication process, and the method of avoiding and eliminating racism is getting to know and interacting with other cultures. It is necessary to talk about prejudice, racism, xenophobia and to seek for equal points of view towards all cultures. Equivalence of cultures is when the majority recognises minorities, conducts an equal dialogue with them and advocates for their rights. Equivalence builds trust and eliminates racism (Paurienè, 2011, pp. 124-125).

Equivalent intercultural interaction is ensured by becoming oriented towards others. Being focused on others means considering the other person's thoughts, feelings, and needs while maintaining their integrity during communication. How does one become focused on others? This can be done in two stages:

- to be socially good;

- be empathetic (Jančaitytė et al., 2009, p. 90).

Emma Arneback and Jan Jämte (Forthcoming) presented a typology of anti-racist actions used by educators in the field of education: 1) emancipatory action. Through these actions, educators aim to critically examine lived experiences and develop students' ability to counter racism and rid them selves of internalized oppression; 2) norm-critical action. These actions aim to make visible, critically examine and challenge social norms through (self-)reflexion; 3) intercultural action. Through these actions, educators aim to create space for cultural diversity and intercultural processes in education; 4) democratic action. The aim of these actions is to involve students (often from different backgrounds and with different opinions and values) in democratic dialogue; 5) relational action. These actions are applied to enable positive self-worth in students through recognition, care, respect and solidarity; 6) knowledge-focused action. Through these actions, educators aim to provide opportunities for knowledge development and critical evaluation of sources of knowledge to prevent racism. The typology of anti-racist action in education presented by Arneback and Jämte looks at the stucturised manifestations of racism (emancipatory, norm-critical and intercultural actions) as well as the individualised manifestations of racism (relational, democratic, and knowledge-focused actions).

A very important part of intercultural education is the development of critical thinking, because the ability to think critically promotes social activism and mutual understanding, respect for different points of view (Norviliene, 2014a, p. 57). This area of education, as mentioned earlier, should also be integrated into the overall pedagogical strategy for the development of intercultural competence. Detailed aspects of critical thinking development have been explored by many authors, such as Jason (2001), Cottrell (2017), Gormley, Jr. (2017), Rutherford (2018).

UNESCO Guidelines on Intercultural Education (2006, pp. 33-38) highlights three main principles of intercultural education: 1) intercultural education emphasises respect for the cultural diversity of learners and the creation of a culturally appropriate and high-quality educational environment; 2) intercultural education must enable every learner to acquire cultural knowledge, develop the appropriate attitudes and abilities that are necessary for active and full-fledged participation in society; 3 ) intercultural education must enable every 
learner to acquire cultural knowledge, develop attitudes and abilities that will allow them to communicate properly with representatives of different cultural, ethnic, social and religious groups, and to feel respect and understanding for them.

It should be noted that in the learning process, the development of intercultural competence must be based on a constructivist paradigm and also experience learning, problembased learning, collaborative learning, reflective learning and cognitive learning strategies. All the listed learning strategies focus on the development of knowledge, abilities, attitudes and the use of prior knowledge in the educational process, creating real and simulated intercultural situations (Gerulaitienè, 2013, p. 25). The combination of the identified teaching strategies allows to achieve excellent results in the development of intercultural competence.

\section{Developing creativity}

\subsection{Development of creativity in an educational institution}

In addition to intercultural competencies, the role of creativity in effective intercultural interaction is no less important. Only a creative person will be able to look creatively at the problems that arise in intercultural interaction and find appropriate solutions to them. The effectiveness of problem solving depends on the ability to adapt existing information very quickly and in a variety of ways. It is the ability to look at a problem from a new point of view, to find non-standard solutions, notice what others have missed. Proponents of the concept of creativity as a problem-solving focus not on the final product, but in the activity itself, which solves complex, unclear, ill-defined problems (Beresnevičius, 2010, pp. 35-36).

Since this work examines creativity mainly as the ability to generate new ideas and solve emerging problems in intercultural interaction, it is necessary to note that a person with such competence must be able to: 1) understand the importance of an intercultural context in the process of generating ideas; 2) accelerate the emergence and application of new non-standard ideas in the context of intercultural communication; 3) make timely decisions; 4) take responsibility for the decisions made; 5) assess the consequences and risks of decisions; 6) to take decisions confidently and firmly in difficult conditions; 7) collect and process information; 8) identify and define problems; 9) argue and justify the decision; 10) make logical, reasoned, constructive remarks; 11) see alternatives in decision-making; 12) not to deviate from the vision in the decision-making process (Peleckis et al., 2016, p. 397).

It is very important to develop people's creativity from an early age. At school, a teacher who fosters creativity, creates an learning environment based on openness and freedom, encourages flexibility and original thinking, creates conditions for learners to experiment, act independently and evaluate themselves positively. The teaching process is organised in such a way that learners constantly have opportunities to exchange ideas, roles, and problems. Pupils are supported not only by presenting the results of creative activity, but are encouraged during the process of searching, testing, research, problem solving (Girdzijauskienè et al., 2011, p. 13).

Various strategies can be used to develop creativity at school: development of cognitive abilities (flexibility of thinking, problem finding, problem solving, etc.), training of creative strategies, development of creativity-friendly attitudes and character building, creation of a 
favourable psychological climate, stimulation by expanding experience, etc. These strategies can be applied individually, but due to the complex nature of creativity, a combination of different strategies is most effective. It applies to lessons in all subjects and to grades at all levels (Vaicekauskienè, 2009, p. 10).

With regard to the development of creativity in higher education, it must be noted that higher education institutions should not only create the right conditions for the development of creative potential, but also apply methods to promote it. It is proposed not only to teach creativity programmes in addition to the subjects of the discipline, but also to integrate creativity itself into individual subjects of the discipline (Ganusauskaite \& Liesionis, 2009, p. 37). It is important that teachers are well prepared to teach creatively, as inappropriate teaching methods can undermine creativity of learners (Soriano de Alencar, 1996, pp. 128-129).

The choice of methods for developing creativity in higher education depends on how creativity is understood. Researchers who consider cognitive creativity components (divergent thinking, problem solving and meta-analysis capabilities, etc.) to be the most important, offer heuristic techniques, brainstorming and divergent thinking techniques, and those who associative mechanisms as the most important component of creativity are more likely to use methods of imagination development. In order to develop personal aspects of creativity (self-expression, openness to experience, not fearing to take risks, etc.), exercises that develop personality creativity are used. If a positive point of view towards creativity and motivation to act creatively are considered to be the most determinants of creativity, methods that determine motivation and points of view towards creativity are used (Grakauskaité-Karkockiené, 2010, pp. 68-69).

Grakauskaitè-Karkockienè (2010, p. 69) notes that some authors (Simonton, 2000; Scott et al., 2004) see creativity as successful exploitation of circumstances and opportunities, therefore propose to apply social interaction techniques to develop creativity.

It should be emphasised, however, that in practice, the various methods of developing creativity that determine the components of creativity are most often used, as they are considered to be more effective.

In higher education, it is very important to promote not only the creative potential of individuals, but also group creativity, because only in the interaction of people the original ideas arise, in addition, working in a group helps to learns to accept criticism and promotes tolerance. The team gains much greater potential for creativity as it combines their knowledge and skills (Ganusauskaitè \& Liesionis, 2009, p. 36). The development of group creativity in higher education is also important due to the fact that effective intercultural subject interaction usually takes place in teams: this is especially true in the case of negotiations. Teamwork corresponds to the so-called "small-world network", one of the most effective forms of social organisation for creativity and tasks. Small worlds have been found to host a remarkable variety of systems, including friendships, collaborations of all kinds, corporate alliances, production teams in business (Černevičiūtė \& Strazdas, 2014, p. 116). When organising teamwork, it is important to remember to facilitate communication between team members. Chen and Agrawal (2017, p. 156) note that "a lack of comfort in communication creates barriers within team members, which impedes discussion and causes others to feel inferior, angry, hostile, dependent, compliant, or subservient". 
Creativity education programmes should eliminate internal and external barriers to creativity, and: 1) to allow participants to perceive the influence of the environment, experience, habits on creative behaviour and to accept oneself as a creative person; 2) to create the right environment for creativity to flourish, taking into account the influence of cultural factors on creativity (Grakauskaitè-Karkockienè, 2010, p. 70).

Armstrong (2009) identified creativity in the context of higher education as follows: 1) creativity of individuals and groups - promotion of individual creativity of students and teachers, and teaching and learning processes; 2) organisational creativity is the promotion of the creative potential of higher education institutions; 3 ) regional creativity is the interaction of higher education institutions with other institutions and society.

Thus, it is very important to realise that the education of a creative society is not restricted to the promotion of the creative potential students. The other two factors mentioned by Armstrong, organisational and regional, also have a major impact. The organisation, in this case higher education institutions, have to build an environment conducive to innovation, flexibility and the ability to adapt to a rapidly changing world, and to manage diversity creatively.

\subsection{Developing creativity in the workplace: institution, organisation}

Creativity education must also be continued when a person works in a particular institution, organisation. In other words, nurturing creativity is a lifelong task. Organisations must be able to communicate effectively with each other internationally, must offer creative solutions to the changing needs of society, otherwise they will not survive.

Organisations need to focus on human resources, which are the main source of creativity. The organisation must promote an open point of view of employees to change, creativity and the ability to solve problems, including those arising in intercultural, especially businesslike, communication. Also, to raise awareness among employees about creativity, knowledge, and flexibility as important aspects of performance that ensure success and life satisfaction in this era of rapid technological change and global integration. Empower employees with more freedom and opportunity in areas or tasks where creativity and innovative potential are important. Encourage employees to develop their creative potential for personal satisfaction. The organisation must train and encourage its employees to work and live creatively (Ganusauskaitė \& Liesionis, 2008, p. 27). According to Kajzer Mitchell and Walinga (2017, p. 1875), the following factors influence the manifestation of creativity: 1) stimulating and rewarding curiosity and exploration; 2) building internal motivation; 3) building confidence and willingness to take risks; 4) encouraging divergent thinking: fluency and flexibility in thinking; 5) encouraging asquisition of domain specific knowledge; 6) encouraging openness to ideas; 7) encouraging building on, or combining ideas from others. Business and organisational leaders should take these factors into account in order to create an environment conducive to creativity.

Two important elements of employee competence development (including creativity competence) can be distinguished: workshop and workplace. The workshop, which is the best form of traditional qualification development, provides knowledge and opportunities to put it into practice in a safe environment. However, if you want to transfer the knowledge gained 
at the workshop to the workplace, then attending the workshop alone will not suffice. It is not possible to transfer the acquired knowledge and skills vertically to other situations without support in the workplace. This means that companies must ensure opportunities to test new skills directly in practice, to collaborate and train each other, and analyse development and implementation (Melnikova \& Trakšelys, 2016, p. 27).

According to Ganusauskaite and Liesionis (2008, p. 28), the creative culture of the organisation is comprised of general characteristics: risk tolerance, attitude towards lifelong learning, openness to change, innovation and creativity characteristics (positive self-esteem, self-confidence, independent behaviour, autonomy, etc.), entrepreneurial characteristics (focus on the use of opportunities, clear motivation of actions, concentration and vision, capital and resource management abilities, positive attitude towards oneself and the environment); characteristics of innovation (openness to critics, empathy, ability to disregard dogmas, etc.).

Particularly in our fast-growing modern society, teams made up of members from different cultures and disciplines are quite common in the workplace. Tang (2019) presents the VICTORY model for fostering creativity in intercultural and interdisciplinary teams. The model aims to draw the attention of researchers and practitioners to key aspects of team creativity (Tang, 2019, p. 7). In order to better understand the importance of factors for different dimensions,

"the components of the VICTORY Model can be classified into three main categories: (1) non-cognitive (vision, openness, risk-taking, Yes-I-Can mindset); (2) cognitive (ideation, creative combination); and (3) environmental (Team and the environmental enablers of the non-cognitive and cognitive components)" (Tang, 2019, p. 7).

The VICTORY model is only structural, but not processual. This limitation is due to the fact that the components of the model are highly interrelated and susceptible to the influence of the environment (Tang, 2019, p. 8).

It is important to realise that as technology advances, intercultural communication is moving into the online virtual environment. Electronic tools such as audio-video conferencing, e-mail, messenger chat, platforms, groups reduce the distance between people from different cultures. International virtual project teams can benefit from cultural diversity and effective cross-cultural communication, which in turn can increase creativity and innovation within the project team. The members of such teams also enrich by acquiring intercultural information and developing of intercultural skills (Dumitraşcu-Băldău \& Dumitraşcu, 2019 , p. 1). Workplaces should adequately train their professionals to work in such international virtual project teams, so that they are able to cope with the challenges of intercultural communication and to work effectively and creatively.

In summary, we can conclude that in today's rapidly changing global environment, only creative organisations that are able to generate and implement new ideas, communicate effectively with each other internationally, adapt quickly and effectively to changing external conditions, and innovate, can become business leaders. In a dynamic environment, timely and high-quality decisions determine not only the outcome of negotiations and the outcome of the agreement, but also the successful functioning and development of the organisation. 


\section{Conclusions}

1. The concept of intercultural competence relates to the readiness to accept differences and includes both social and cultural aspects. Researchers are not unanimous on the definition of intercultural competence, they define it in different ways and present different models. Summarising the models presented in the scientific literature, it can be stated that the following levels are distinguished in the models of all authors: 1) level of cognition; 2) emotional level; 3) level of behaviour.

2. There is no doubt about the importance of intercultural competence in intercultural interaction. Acquired intercultural competence skills help us to communicate effectively with representatives of other cultures both during private trips, travels, and in the context of business intercultural interaction.

3. The "approach" itself to representatives of cultures of different mentalities should be original, creative, therefore, it is clear that effective intercultural communication must contain elements of creativity. This trait must be developed. Creativity is often associated with the ability to generate new ideas and solve problems. In intercultural interaction, various problems arise constantly. If the solution of the problem corresponds to the criteria of the creative work, in intercultural interaction, as in other life situations, the solution of the problem (as a process) can be considered as creative thinking. The importance of creative thinking is not only significant in informal communication between people of different nationalities, but also in intercultural business communication, such as intercultural teams, international negotiations or other international meetings of a similar nature, where it is necessary to find solutions that are acceptable to all communicating parties.

4. In intercultural competence, three levels can be distinguished that need to be fostered: linguistic, communication and cultural competence. Only the unity of these three competencies can ensure a successful intercultural dialogue. In the opinion of the author, Byram's (1997) model of intercultural competence is very important in developing intercultural competence. In this article, we reviewed the specific intercultural competencies to be developed using the model of intercultural competence of the said researcher, i.e. by classifying the various abilities, skills, and knowledge to be developed in accordance with the dimensions of the intercultural competence model identified by the author.

5. The following areas can be distinguished in the pedagogical concept - coexistence of cultures, comparison of cultures, anti-racism, development of critical thinking, which can be considered as a pedagogical strategy for the development of intercultural competence. In the author's view, typology of anti-racist actions of Arneback and Jämte (Forthcoming) is of great relevance for anti-racist education. Educators, therefore, should apply these actions to the education of their students depending on a situation.

6. It should be noted that in the learning process, the development of intercultural competence must be based on a constructivist paradigm and also experience learning, problembased learning, collaborative learning, reflective learning and cognitive learning strategies. The combination of the identified teaching strategies allows to achieve excellent results in the development of intercultural competence. 
7. Creativity must be developed from an early age. Only a creative person will be able to look creatively at the problems that arise in intercultural interaction and find appropriate solutions to them. In higher education, various methods of creativity education that determine the components of creativity are most often used in practice: heuristic techniques, brainstorming and divergent thinking methods, imagination development techniques, exercises that develop personality creativity, methods that determine motivation and points of view towards creativity, social interaction techniques. Creativity education must also be continued when a person works in a particular institution, organisation. Organisations must be able to communicate effectively with each other internationally, must offer creative solutions to the changing needs of society, otherwise they will not survive.

8. In order to ensure effective intercultural communication, it is necessary to combine intercultural competences with creativity competences.

\section{References}

Alexandrache, C. (2019). Studying national culture - modality to develop intercultural competences in Higher Education. In E. Soriano, Ch. Sleeter, M. A. Casanova, R. M. Zapata, V. C. Cala (Eds.), The European Proceedings of Social and Behavioural Sciences. Vol. 60. VIII International Conference on Intercultural Education and International Conference on Transcultural Health: The Value of Education and Health for a Global, Transcultural World: EDUHEM 2018 (pp. 54-61). Almeria, Spain. Future Academy. https://doi.org/10.15405/epsbs.2019.04.02.8

Armstrong, L. (2009). Creativity and the research university. In Changing Higher Education. https:// www.changinghighereducation.com/2009/01/creativity-and-the-research-university.html

Arneback, E., \& Jämte, J. (Forthcoming). How to counteract racism in education - a typology of teachers' anti-racist actions. Race Ethnicity and Education. https://doi.org/10.1080/13613324.2021.1890566

Berardo, K., \& Deardorff, D. K. (2012). Building cultural competence: innovative activities and models. Stylus Publishing, LLC.

Beresnevičius, G. (2010). Kūrybiškumo ir kūrybinio mąstymo edukacinès dimensijos [disertacija]. Lucilijus.

Byram, M. (1997). Teaching and assessing intercultural communicative competence. Multilingual Matters.

Carrió-Pastor, M. L., \& Bellés-Fortuño, B. (Eds.). (2021). Teaching language and content in multicultural and multilingual classrooms: CLIL and EMI approaches. Palgrave Macmillan. https://doi.org/10.1007/978-3-030-56615-9

Chen, M.-H., \& Agrawal, S. (2017). Do communication barriers in student teams impede creative behavior in the long run? - A time-lagged perspective. Thinking Skills and Creativity, 26, 154-167. https://doi.org/10.1016/j.tsc.2017.10.008

Cottrell, S. (2017). Critical thinking skills: effective analysis, argument and reflection. Series: Macmillan Study Skills. Red Globe Press. https://doi.org/10.1057/978-1-137-55052-1

Council of Europe. (2002). Common European framework of reference for languages: learning, teaching, assessment. Cambridge University Press.

Cropley, A. J. (1999). Definitions of creativity. In M. A. Runco \& S. R. Pritzker (Eds.-in-Chief). Encyclopedia of Creativity, Vol. 1. (pp. 511-524). Academic Press.

Černevičiūtè, J., \& Strazdas, R. (2014). Kūrybingumo sampratų raida: nuo genijaus ị kūrybines sistemas. Santalka: filosofija, komunikacija, 22(2), 113-125. 
Deardorff, D. K. (Ed.). (2009). The SAGE Handbook of Intercultural Competence. SAGE Publications, Inc.

Domingo, H. G. (2018). Assessing intercultural communicative competence: diploma thesis. GRIN Verlag.

Dumitraşcu-Băldău, I., \& Dumitraşcu, D. D. (2019). Intercultural communication and its challenges within the international virtual project team. In MATEC Web of Conferences, 290. https://doi.org/10.1051/matecconf/201929007005

Fantini, A. E. (2019). Intercultural comunicative competence in educational exchange: a multinational perspective. Series: Routledge Research in Teacher Education. Routledge. https://doi.org/10.4324/9781351251747-2

Ganusauskaite, A., \& Liesionis, V. (2008). Kūrybinis procesas ir jo potencialo skatinimas organizacijoje. Organizaciju vadyba: sisteminiai tyrimai, 48, 23-34.

Ganusauskaitė, A., \& Liesionis, V. (2009). Lietuvos aukštojo mokslo perspektyva - kūrybinès visuomenès ugdymas. Vadyba: mokslo tiriamieji darbai, 1(14), 33-39.

Garrido, C., \& Álvarez, I. (2006). Language teacher education for intercultural understanding. European Journal of Teacher Education, 29(2), 163-179. https://doi.org/10.1080/02619760600617342

Geistmann, Ch. (2002). Interkulturelle Kompetenz - Eine wichtige und förderbare Fähigkeit in der internationalen Zusammenarbeit: Entwicklung eines Konzeptes zur schrittweisen Förderung interkultureller Kompetenz aufgezeigt am Beispiel der Handelspartner Frankreich und Deutschland. Books on Demand, GmbH.

Gerulaitienè, E. (2013). Patirtinio mokymosi kitame kultūriniame kontekste ugdymo praktikos, plètojant tarpkultūrinę kompetenciją, ypatumų analizè. Jaunųjų mokslininkų darbai, 1(39), 25-31.

Girdzijauskienė, R., Penkauskienè, D., Sruoginis, L. V., Bukantienė, J., Grinytė, L., \& Matonytė, A. (2011). Kürybiškumo ugdymui palankios aplinkos mokykloje tyrimas: tyrimo ataskaita. http://11a.lt/ $\mathrm{krsc} / \mathrm{p} /$ kurybiskumas/d/aplinkos_tyrimas.pdf

Gormley, Jr. W. T. (2017). The critical advantage: developing critical thinking skills in school. Harvard Education Press.

Grakauskaitè-Karkockienė, D. (2010). Kūrybiškumo ugdymas: teoriniai ir praktiniai aspektai. Ugdymo psichologija, 21, 66-74.

Grebliauskienè, B., \& Večkienè, N. (2004). Komunikacinè kompetencija: komunikabilumo ugdymas. Žara.

Griffiths, Ch., \& Costi, M. (2019). The creative thinking handbook: your step-by-step guide to problem solving in business. Kogan Page.

Herbrand, F. (2000). Interkulturelle Kompetenz: Wettbewerbsvorteil in einer globalisierenden Wirtschaft. Paul Haupt Verlag.

Hinz-Rommel, W. (1994). Interkulturelle Kompetenz. Ein neues Anforderungsprofil fuer die soziale Arbeit. Waxmann.

Jackson, J. (2014). Introducing language and intercultural communication. Routledge. https://doi.org/10.4324/9781315848938

Jančaitytė, R., Valavičienè, N., Augutienè, R., \& Prakapas, R. (2009). Tarpkultūrinès kompetencijos didinimas bei įvairovés valdymo gebejjimu stiprinimas. Tarptautinès migracijos organizacijos Vilniaus biuras / Mykolo Romerio Universitetas.

Jandt, F. E. (2020). An introduction to intercultural communication: identities in a global community. SAGE Publications, Inc.

Jandt, F. E. (2000). Intercultural communication: an introduction. SAGE Publications, Inc.

Jason, G. (2001). Critical thinking: developing an effective worldview. Wadsworth Group.

Jiaquan, X. (2009). On the development of college students' intercultural competency intercultural competency. International Forum of Teaching and Studies, 5(2), 27-31. 
Kajzer Mitchell, I., \& Walinga, J. (2017). The creative imperative: the role of creativity, creative problem solving and insight as key drivers for sustainability. Journal of Cleaner Production, 140(3), 1872-1884. https://doi.org/10.1016/j.jclepro.2016.09.162

Lustig, M. W., \& Koester, J. (2012). Intercultural competence: interpersonal communication across cultures. Pearson.

Maletzke, G. (1996). Interkulturelle Kommunikation: Zur Interaktion zwischen Menschen verschiedener Kulturen. Westdeutscher Verlag. https://doi.org/10.1007/978-3-322-80350-4

Martin, J. N., \& Nakayama, Th. K. (2018). Intercultural communication in contextsMcGraw-Hill Education.

Mauricienè, I. (2013). Tarpkultūrinių kompetencijų raiška aukštojo mokslo institucijoje. Socialiniai mokslai, 1(22), 31-36.

Mažeikienè, N., \& Loher, D. (2008). Teachers' intercultural competence in mobility programme preview. Socialiniai mokslai, 2, 48-65.

Mažeikienè, N., \& Virgailaitè-Mečkauskaite, E. (2007). The experience of measurement and assessment of intercultural competence in education. Socialiniai mokslai, 4(58), 70-82.

McConachy, T. (2018). Developing intercultural perspectives on language use: exploring pragmatics and culture in foreign language learning. Series: Languages for Intercultural Communication and Education. M. Byram, \& A. J. Liddicoat (Eds.). Vol. 33. Multilingual Matters. https://doi.org/10.21832/9781783099337

Melnikova, J., \& Trakšelys, K. (2016). Darbuotojų inovatyvumo ir kūrybiškumo kompetencijos ugdymo(si) principai. Holistinis mokymasis, 2, 21-30.

Neuliep, J. W. (2012). Intercultural communication: a contextual approach. SAGE Publications, Inc.

Norvilienè, A. (2014a). Kryptingas tarpkultūrinis studentu ugdymas, kaip tarpkultūrinès kompetencijos tobulinimo veiksnys (mokytoju rengimo universitete atvejis) [daktaro disertacija, Klaipèdos universitetas. Klaipeda, Lietuva]. https://vb.ku.lt/object/elaba:2120963/index.html

Norvilienè, A. (2014b). Tarpkultūrinès studentų kompetencijos ugdymo(si) veiksniai. Socialinis ugdymas, 38(2), 40-55. https://doi.org/10.15823/su.2014.04

Partnership for 21st Century Skills. (2008). 21st century skills, education and competitiveness: a resource and policy guide. http://wieettassessment.pbworks.com/f/21stCenturySkillsEducationandCompetitivenessGuide.pdf

Paurienè, G. (2011). Tarpkultūrinè kompetencija ir jos ugdymas pareigūnų rengime. Visuomenés saugumas ir viešoji tvarka, 5, 114-128.

Peleckis, K. (2014). International business negotiations: innovation, negotiation team, preparation. Procedia - Social and Behavioral Sciences, 110, 64-73. https://doi.org/10.1016/j.sbspro.2013.12.848

Peleckis, K., Mažeikienė, A., Peleckienè, V., \& Peleckis, K. (2016). Verslo komunikacija ir derybos. Technika. https://doi.org/10.20334/1556-S

Peleckis, K., Peleckienė, V., \& Peleckis, K. (2013a). Tarptautinès verslo derybos: inovacijos, derybų komanda, pasiruošimas. Vadyba: mokslo tiriamieji darbai, 23(2), 39-45.

Peleckis, K., Peleckienè, V., \& Peleckis, K. (2013b). Verslo vadybos studentų derybinių kompetenciju ugdymas: struktūros ir turinio dimensijos. Verslas: teorija ir praktika, 14(4), 346-357. https://doi.org/10.3846/btp.2013.37

Petkevičiūtė, N., \& Budaite, R. (2005). Vadovų tarpkultūrinè kompetencija Lietuvos organizacijose. Organizaciju vadyba: sisteminiai tyrimai, 36, 132-149.

Pruskus, V. (2011). Kompetencijų vaidmuo sprendžiant tarpkultūrinius konfliktus. Logos: religijos, filosofijos, komparatyvistikos ir meno žurnalas, 67, 142-152.

Pruskus, V. (2004). Multikultūrinè komunikacija ir vadyba. Vilniaus teisès ir verslo kolegija. 
Pruskus, V. (2013). Tarpkultūriniai konfliktai: kilimo priežastys ir kompetencijų vaidmuo. Santalka: filosofija, komunikacija, 21(2), 79-89. https://doi.org/10.3846/cpc.2013.08

Rakauskaitė, E. D. (2014). Kūrybingumo ugdymas - investicija ị kūrybinę visuomenę. Socialinès technologijos, 4(2), 333-347. https://doi.org/10.13165/ST-14-4-2-07

Rothman, J. C. (2007). Cultural competence in process and practice: building bridges. Pearson Education.

Ruggiero, V. R. (2011). The art of thinking: a guide to critical and creative thought. Pearson Longman.

Rutherford, A. (2018). A fundamental guide to effective decision making, deep analysis, intelligent reasoning, and independent thinking: elements of critical thinking. Independently Published.

Samovar, L. A., Porter, R. E., \& McDaniel, E. R. (2011). Intercultural communication: a reader. Cengage Learning.

Savanevičienè, A., \& Gudonavičius, L. (2007). Kūrybiškumo rolè priimant strateginius sprendimus. Ekonomika ir vadyba, 12, 636-642.

Scott, G., Leritz, L. E., \& Mumford, M. D. (2004). The effectiveness of creativity training: a quantitive review. Creativity Research Journal, 16(4), 361-388. https://doi.org/10.1080/10400410409534549

Simonton, D. K. (2000). Creativity: cognitive, personal, developmental, and social aspects. American Psychologist, 55(1), 151-158. https://doi.org/10.1037/0003-066X.55.1.151

Soriano de Alencar, E. M. L. (1996). University Students' evaluation of their own level of creativity and their teachers' and colleagues' level of creativity. Gifted Education International, 11(3), 128-130. https://doi.org/10.1177/026142949601100303

Stancikas, E. (2015). Kultūrinio sąmoningumo ugdymas. Tiltai, 70(1), 127- 140. https://doi.org/10.15181/tbb.v69i1.1055

Stone, N. (2006). Internationalising the student learning experience: possible indicators. Journal of Studies in International Education, 10(4), 409-413. https://doi.org/10.1177/1028315306287633

Tang, M. (2019). Fostering creativity in intercultural and interdisciplinary teams: The VICTORY Model. Frontiers in Psychology, 10. https://doi.org/10.3389/fpsyg.2019.02020

Tracy, B. (2010). Tikslai: pakilkite ị viršūnę greičiau, nei kada nors svajojote. Luceo.

United Nations Educational, Scientific and Cultural Organization. (2006). UNESCO guidelines on intercultural education. United Nations Educational, Scientific and Cultural Organization.

Vaicekauskienè, V. (2009). Kūrybingumo (ne)ugdymas mokykloje. Švietimo problemos analizè, 3(31), $1-12$.

Vaičiūnienė, V. (2015). Bendravimo gimtąja ir užsienio kalbomis perspektyva suaugusiųjų švietime: kompetencija grindžiamas požiūris. Holistinis mokymasis, 1, 25-35.

Virgailaitè-Mečkauskaitè, E. (2011). Tarpkultūrinès kompetencijos ugdymas aukštojo mokslo internacionalizacijos kontekste (magistrantūros studijų aspektas) [daktaro disertacija]. Šiaulių universiteto leidykla.

Wallas, G. (2014). The art of thought. Solis Press.

Wiseman, R. L., \& Koester, J. (Eds.). (1993). Intercultural communication competence. Series: International and Intercultural Communication Annual. Vol. 17. SAGE Publications.

Zaldivar, E. J. (2020). Your unique cultural lens: a guide to cultural competence. Independently Published. 